\title{
Studies on Biochemical Role of Accumulation of Heavy Metals in Safflower
}

\author{
Nidhi Madaan ${ }^{1}$, Varsha Mudgal ${ }^{1}$, Sanjay Mishra ${ }^{1,2, *}$, A.K. Srivastava ${ }^{3}$ and R.B. Singh $^{4}$ \\ ${ }^{I}$ Department of Biotechnology and Microbiology, Institute of Foreign Trade \& Management, Lodhipur Rajput, \\ Delhi Road, Moradabad 244 001, UP, India \\ ${ }^{2}$ Department of Biotechnology, College of Engineering \& Technology, IFTM Campus, Moradabad 244 001, UP, India \\ ${ }^{3}$ Department of Botany, CCS University, Meerut, UP, India \\ ${ }^{4}$ Halberg Hospital and Research Center, Civil Lines, Moradabad 244 001, UP, India
}

\begin{abstract}
Phytoremediation is the biotechnological application of plants to detoxify pollutants, and is a modern technique for environmental clean-up. Plants are ideal agents for soil and water remediation because of their unique genetic, biochemical and physiological features. Thus, the accumulation of mercury and Selenium was estimated in the roots, mature leaves and seeds of safflower (Carthamus tinctorius L), grown hydroponically in $10^{4} \mathrm{M}$ solution for both phenyl mercuric acetate and selenium-dioxide for eight days. The tolerance was quantified followed by categorizing as: categorized tolerant, partially tolerant and non-tolerant, employing the Response Coefficient parameter. Fifteen accessions as five each for tolerant, partially tolerant and non-tolerant were used for estimating the accumulation of various pollutants in roots, mature leaves and seeds. Conclusively, the present study provides new insights into products can be extracted with negligible concentration of mercury and selenium occurring in aerial parts of this economically and nutraceutically significant plant.
\end{abstract}

Keywords: Carthamin, Carthamus tinctorius L., Phenyl mercuric acetate, Selenium-dioxide.

\section{INTRODUCTION}

Heavy metals are important environmental pollutants, and are mostly toxic even at very low concentrations [1]. Pollution of the biosphere with toxic metals has been monitored to dramatically accelerate since the initiation of the industrial revolution [2]. The basic sources of this pollution are the burning of fossil fuels, the mining and smelting of metalliferous ores, municipal wastes, fertilizers, pesticides, sewage etc. [3]. Soil pollution is caused by the existence of xenobiotics or other chemical alterations in the natural soil environment. This type of specific contamination arises mainly from the rupture of underground storage tanks, application of pesticides and percolation of contaminated surface water to subsurface strata. Besides, oil and fuel dumping, leaching of wastes from landfills and direct discharge of industrial wastes to the soil may also be considered as causatives for pollution of the biosphere. The most common chemicals involved are petroleum hydrocarbons, solvents, pesticides, lead and other heavy metals. Heavy metals occupy considerably lethal position because of threat to human health, owing to their toxicity. The toxicological information regarding mercury was evident in the victims of a tragic occurrence of methyl mercury poisoning in Japan (Minimata disaster) in 1950's when there were 111 human casualties resulting from the consumption of fish contaminated with mercury caught in Minimata Bay. The

*Address correspondence to this author at the School of Biotechnology, IFTM University, Lodhipur Rajput, Delhi Road (NH-24), Moradabad 244 001, U.P., India; Tel: +91-591-2360818; Fax: +91-591-2360817;

E-mail: sanjaymishra66@gmail.com bay got contaminated with mercury released from vinyl chloride plant. In fact, the mercury is discharged into the environment as metallic, inorganic and/or organic mercuric compounds. This may probably enter the bio-geochemical cycle by simple transport in the form of metallic mercury vapor, transformed into volatilized organic mercury compounds and/or by chemical transformation into more soluble salts or mercury based conjugated compounds. Mercury, in general, is extremely toxic undergoes certain changes in the soil to get discharged as vapors or recombined with various oxides, chlorides and acetates, ultimately, leading to poisonous condition in human beings.

Selenium occurs naturally in the environment, released through both natural processes and human activities. Selenium uptake through food is usually high enough to meet human needs; shortages rarely occur. When shortages occur people may experience cardio-vascular and muscular disorders $[3,4]$. The health effects of various forms of selenium can vary from brittle hair and deformed nails, to rashes, heat, swelling of the skin and severe pains. When selenium ends up in the eyes people experience burning, irritation and tearing. Selenium poisoning may become so severe in some cases that it can even cause death. Overexposure of selenium fumes may lead to accumulation of fluid in the lungs, garlic breath, bronchitis, pneumonitis etc. Selenium is an eye and upper respiratory irritant and a sensitizer. Selenium dioxide reacts with moisture to form selenious acid, corrosive to the skin and eyes. But, nevertheless, It was considered as an essential trace element for human health in 1990 [4]. Dietary selenium is important for a healthy immune response [5]. The effects of Se deficiency can include reduced T-cell 
counts, impaired lymphocyte proliferation and responsiveness [6]. Dietary supplementation of humans with $200 \mathrm{mg}$ of sodium selenite enhances T-lymphocyte immune responses [7]. There is strong evidence that Se plays a pivotal role against some forms of cancer, including oral cancer [8]. In a recent study involving 1312 patients supplemented with $200 \mathrm{mg}$ Se daily, the incidence of prostate, colon and lung cancers was decreased by 63,58 , and $46 \%$ respectively [9].

The present studies were undertaken in view of providing an impeccable hypothesis that safflower may probably be employed as a potent phytoremediator of mercury $(\mathrm{Hg})$ and selenium (Se) from polluted soils.

\section{MATERIALS AND METHODS}

An accession can be defined as an ecotype. An ecotype sometimes called ecospecies, describes a genetically distinct geographic variety, population or race within species (or among closely related), which is adapted to specific environmental conditions. Typically, ecotypes exhibit phenotypic differences (such as in morphology or physiology) stemming from environmental heterogeneity and are capable of interbreeding with other geographically adjacent ecotypes without loss of fertility or vigor [10-12].

Two hundred and thirty four accessions of safflower, procured by the courtesy of United States Department of Agriculture (USDA), All India Coordinated Research Project on Oil Seeds (AICRPO), National Bureau of Plant Genetic Resources (NBPGR) and Directorate of Oil Research (DOR) were subjected to tests for response to organic mercury and selenium. Fifty seeds of each accession were grown in sterilized petriplates lined with cotton pads, sandwiched between filter papers. Treated sets for mercury were raised in $10^{-4} \mathrm{M}$ solution of phenyl mercuric acetate (PMA) and for selenium in $10^{-4} \mathrm{M}$ selenium-dioxide $\left(\mathrm{SeO}_{2}\right)$. Control sets were raised in Hoagland's solution lacking PMA and $\mathrm{SeO}_{2}$. Both control and treated sets were raised in Calton's Seed Germinator in total darkness at $25^{0} \mathrm{C}-27^{0} \mathrm{C}$ for seven days $[13,14]$. On the basis of radical lengths of seven days old seedlings Response Coefficient (RC) was calculated using the following formula:

$$
\mathbf{R C}=\frac{\text { VT-VC }}{\text { VC }}
$$
set)

(VT = value of the treated set; $\mathrm{VC}=$ value of the control

The negative values of RCs indicated inhibition while positive values indicated stimulation. After calculating $\mathrm{RC}$ for each accession on the basis of radical length, they were categorized into three categories basing upon their value for $\mathrm{RC}$,

Tolerant $(\mathrm{T})=>-0.20$

Partially tolerant $(\mathrm{PT})=-0.20$ to -0.79

Non-tolerant $(\mathrm{NT})=<-0.80$.

On the basis of above calculations, in case of mercury $27.78 \%$ accessions were found to be tolerant (T), $61.12 \%$ accessions were partially tolerant (PT) and $11.1 \%$ accessions were non-tolerant (NT). However, in response to selenium treatment, $4.27 \%$ accessions were tolerant (T), 50\% accessions were partially tolerant (PT) and $45.73 \%$ accessions were non-tolerant (NT). Thereafter, five accessions each were chosen for mercury and selenium from tolerant, partially tolerant and non-tolerant categories.

Estimation of the mercury and selenium accumulation was done in roots, mature leaves and seeds of safflower. Study materials were cultured in $10^{-4} \mathrm{M}$ PMA and $\mathrm{SeO}_{2}$ prepared in Hoagland's solution at a room temperature between $20-25^{\circ} \mathrm{C}$ in sterilized conditions. For this study, five tolerant (T-8, T-124, T-143, T-163, T-188), five partially tolerant (T21, T-28, T-44, T-136, T-170) and five non-tolerant (T-2, T3, T-6, T-106, T-161) plants each for mercury and selenium were taken. Roots, mature leaves and seeds available after 8 days of water culture were analyzed for mercury and selenium accumulation. The amount of roots, mature leaves and seeds generated was variable ranging from $0.3 \mathrm{gms}$ to 10 gms, however, for the further studies only $100 \mathrm{mg}$ each of roots, mature leaves and seeds was used. For estimating accumulation of pollutants in seeds, plants with seeds were opted which were later cultured for eight days in the same media and conditions as provided to the roots and mature leaves. Oven dried $100 \mathrm{mg}$ roots, mature leaves and seeds were properly digested in $5 \mathrm{ml}$ of $1: 1(\mathrm{v} / \mathrm{v})$ concentrated nitric acid and perchloric acid. $\left(\mathrm{HClO}_{4}\right)$. The residual digested matter was finally dissolved in $10 \mathrm{ml}$ of double glassdistilled water. Mercury and selenium accumulates were estimated using Flame Atomic Absorption Spectrometer (FAAS) at $196 \mathrm{~nm}$ at Indian Institute of Technology (IIT), Roorkee, India. All liquid samples were aspirated, aerosolized and mixed with combustible gases, such as acetylene and air or acetylene and nitrous oxide. The mixture was ignited in a flame ranging from 2100 to $2800^{\circ} \mathrm{C}$. During combustion, atoms of the element of interest in the sample were reduced to free, unexcited ground state atoms absorbing light at characteristic wavelengths. The characteristic wavelengths were element specific and accurate to $0.01-0.1 \mathrm{~nm}$. To provide element specific wavelengths, a light beam from a lamp whose cathode was made of the element being determined is passed through the flame. A device such as a photon multiplier could detect the amount of reduction of the light intensity due to absorption by the analyte being directly related to the amount of the element in the sample. Light of the appropriate wavelength was supplied and the amount of light absorbed could be measured against a specific standard curve.

\section{RESULTS}

The accumulation of mercury in safflower accessions is shown in Fig. (1). In mercury treated plants, roots absorbed more mercury in comparison to the mature leaves and seeds. T-161 (NT) accession showed maximum mean absorbance of $0.0832 \mu \mathrm{g} / \mathrm{mL}$ and accessions T-2 (NT) and T-6 (NT) showed minimum mean absorbance of $0.0532 \mu \mathrm{g} / \mathrm{mL}$, in roots. However, in the mature leaves, maximum mean absorbance was noticed in the accessions T-28 (PT) and T-3 (NT) of $0.0421 \mu \mathrm{g} / \mathrm{mL}$ and minimum was observed in T-124 (T) accession of $0.0222 \mu \mathrm{g} / \mathrm{mL}$. The least amount was accumulated in the seeds amongst all the three estimated plant parts. Maximum mean absorbance in seeds was observed in T-6 (NT) accession of $0.0121 \mu \mathrm{g} / \mathrm{mL}$ and minimum mean absorbance was concluded in T-124 (T) of $0.0007 \mu \mathrm{g} / \mathrm{mL}$. 


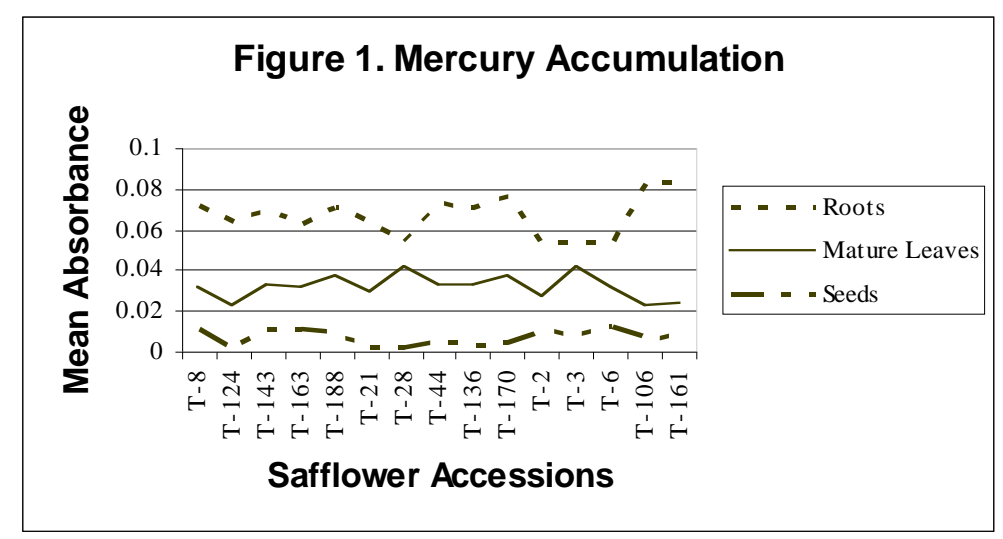

Fig. (1). Accumulation of mercury in roots, mature leaves and seeds of safflower. Values are mean \pm SD of three sets of experiments with triplicates in each set.

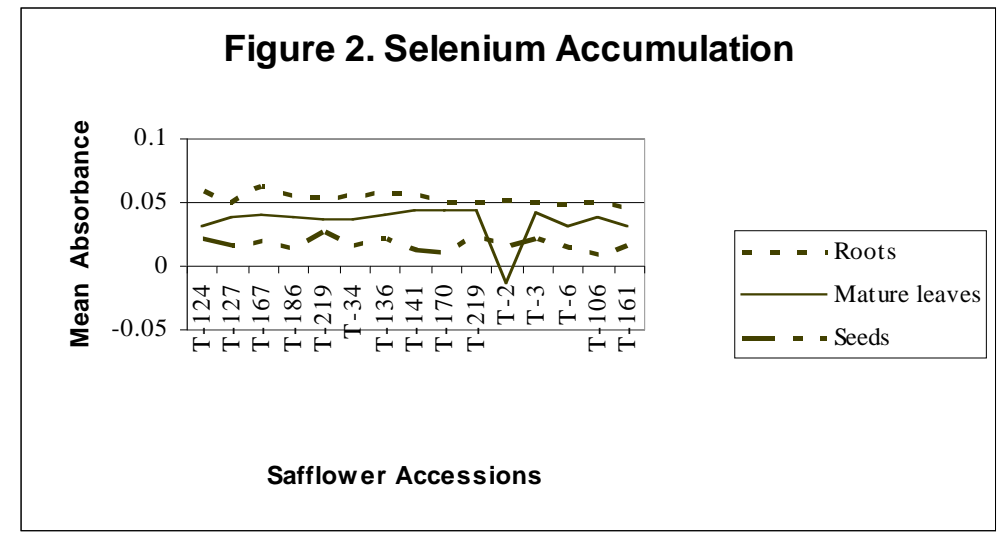

Fig. (2). Accumulation of selenium in roots, mature leaves and seeds of safflower. Values are mean $\pm \mathrm{SD}$ of three sets of experiments with triplicates in each set.

Accumulation of selenium in safflower accessions is shown in Fig. (2). Results were similar in response to the mercury treatment on the same plant parts, namely, roots, mature leaves and seeds in safflower. Roots accumulated highest amount of Se followed by mature leaves and seeds. In roots, maximum mean absorbance in response to selenium treatment was observed in T-167 (T) of $0.0625 \mu \mathrm{g} / \mathrm{mL}$ and minimum absorbance was observed in T-161 (NT) of 0.0453 $\mu \mathrm{g} / \mathrm{mL}$. In mature leaves, $\mathrm{T}-219$ ( $\mathrm{T}$ ) showed maximum mean absorbance of $0.0433 \mu \mathrm{g} / \mathrm{mL}$ while T-2 (NT) showed minimum mean absorbance of $-0.0148 \mu \mathrm{g} / \mathrm{mL}$. Minimum amount of selenium was accumulated in seeds in contrast to the mature leaves and roots. Maximum mean absorbance was expressed by $\mathrm{T}-219(\mathrm{~T})$ of $0.0261 \mu \mathrm{g} / \mathrm{mL}$ and minimum mean absorbance was showed by T-106 (NT) of 0.0090 $\mu \mathrm{g} / \mathrm{mL}$.

\section{DISCUSSION}

The accumulation of mercury and selenium was high in the roots, probably as roots are in direct contact with the soil, which helps them to absorb all the nutrients present in the soil. Further it is translocated to the upper parts of the plant namely, shoot whereby its concentration is not same as roots. Transporters are required for exclusion of a toxic metal ion, transporting the metal into the apoplastic space and transporting the metal into the vacuole where it would be less likely to exert a toxic effect [15]. When overexpressing lines, exposed to lethal concentrations of $\mathrm{Zn}$ or $\mathrm{Cd}$, translocated these metals at a greater extent to the shoot, in contrast, the metal level was found to be rather similar in roots, indicating that the metal uptake by the roots compensated for the increased metal translocation to the shoot [16]. The vacuole is considered to be the main sequestering site for metals in yeast as well as plant cells $[15,16]$. YCF1 strain of Saccharomyces cerevisiae is the best known vacuolar transporters. It is $\mathrm{Mg}^{+}-\mathrm{ATP}$-energized glutathione S-conjugate transporter system [17]. Other transporter proteins that could be of value probably include: - the A. thaliana antiporter CAX2 [18], LCT1, a nonspecific transporter for $\mathrm{Ca}^{2+}, \mathrm{Cd}^{2+}, \mathrm{Na}^{+}$and $\mathrm{K}+$ [19], the Thlaspi caerulescens heavy metal ATPase, TcHMA4 [19, 20], a novel family of cysteine rich membrane proteins that mediate $\mathrm{Cd}$ resistance in $A$. thaliana and AtMRP3, an ABC transporter [21].

\section{RESPONSE OF HEAVY METALS TO PLANTS}

Plants have developed three basic strategies for growing on contaminated and metalliferous soils [22].

1. Metal excluders: These plants effectively prevent metal from entering their aerial parts over a broad range of metal concentrations in the soil; however, they can still contain large amounts of metals in their roots. 
2. Metal indicators: These plants accumulate metals in their above-ground tissues and the metal levels in the tissues of these plants generally reflect metal levels in the soil.

3. Accumulators: These plant species (hyper accumulators) can concentrate metals in their above-ground tissues to levels far exceeding those present in the soil or in the nonaccumulating species growing nearby. It has been proposed that a plant containing more than $0.1 \%$ of $\mathrm{Ni}$, $\mathrm{Co}, \mathrm{Cu}, \mathrm{Cr}$ or $\mathrm{Pb}$ or $1 \%$ of $\mathrm{Zn}$ in its leaves on a dry weight basis is called a hyper accumulator, irrespective of the metal concentration in the soil [3]. The information related to accumulator plants is most needed in four areas: first, the metal accumulating ability of various species as a function of soil metal concentrations, physical and chemical soil properties, physiological state of the plant, etc.; second, the specificity of metal uptake, transport and accumulation; third, the physiological, biochemical and molecular mechanisms of accumulation and hyperaccumulation; and fourth, the biological and evolutionary significance of metal accumulation.

\section{PHYTOREMEDIATION OF MERCURY}

Pistia stratiotes exhibited different patterns of response to $\mathrm{Ag}, \mathrm{Cd}, \mathrm{Cr}, \mathrm{Cu}, \mathrm{Hg}, \mathrm{Ni}, \mathrm{Pb}$ and $\mathrm{Zn}$, and although concentrations as high as $5 \mathrm{mM}$, all the elements accumulated at high concentrations mainly in the root system. This plant species exhibited the highest tolerance index to $\mathrm{Zn}$ and the lowest to Hg. Spartina plants have been shown to be 3-fold more tolerant to $\mathrm{Hg}$ than tobacco plants, due to an ability to absorb organic $\mathrm{Hg}$ and transform it into an inorganic form $\left(\mathrm{Hg}^{+}, \mathrm{Hg}^{2+}\right)$. The inorganic $\mathrm{Hg}$ then accumulates in the underground parts of the plants and is transferred back to the soil by diffusion and permeation, indicating that this species may be used in the phytoremediation of an $\mathrm{Hg}$ polluted environment [23]. The water Fern Azolla caroliniana (Azollaceae) could be serve as hyper accumulator thus can purify waters polluted by mercury and chromium [23, 24].

\section{PHYTOREMEDIATION OF SELENIUM}

Selenium (Se) is a toxic metal at medium to high concentrations but essential as a micronutrient for humans and animals. It occurs naturally in soils as selenate and selenite and often as a pollutant, following the industrial use of coal. Se and sulphur (S) have very similar chemical properties so it incorporates in proteins as selenomethionine and proceed by the same enzymes of methionine. Some scientist worked to obtain selenium tolerant plants by overexpression of genes encoding key enzymes in sulphur metabolism. Some plants overexpressing ATP sulphurylase, were shown to have higher shoot Se concentrations and enhanced Se tolerance than wild type when grown in the presence of selenate in either hydroponic systems or soil like Brassica juncea, Arabidopsis thaliana and Astragalus bisulcatus [25]. Transgenic plants that were over expressing ATP sulphurylase, were more tolerant than the wild type to $\mathrm{As}(\mathrm{III}), \mathrm{As}(\mathrm{V}), \mathrm{Cd}$, $\mathrm{Cu}, \mathrm{Hg}$, and $\mathrm{Zn}$, but less tolerant to Mo and $\mathrm{V}$ [26]. They also over expressing cystathionine- $\gamma$-synthase (CGS) showed a higher Se volatilization rate, lower shoot Se levels, and higher Se tolerance than wild type. A. bisulcatus has the ca- pacity to accumulate Se to high concentrations but it has a slow growth rate. It has been proposed that in selenocysteine methyltransferase (SMT) specifically methylates selenocysteine (SeCys) to produce the nonprotein amino acid methylselenocysteine MetSeCys, which causes a reduction in the intracellular concentrations of SeCys and selenomethionine (SeMet), thus preventing their incorrect insertion into protein [27]. Brassica juncea overexpressing the A. bisulcatus SMT gene, exhibited a greatly increased accumulation of MetSeCys and tolerance to Se compounds, in particular selenite [28].

\section{ACCUMULATION OF HEAVY METALS IN SAFFLOWER}

In the present study, the accumulation of mercury and selenium in shoots indicated that in most of the accessions, mercury and selenium could be translocated from roots to shoots. However, results compiled reflect that the least amount accumulated in the seeds, intermediate in the mature leaves and maximum accumulated in the roots, these findings helps in maintaining the economic importance of safflower as such as its oil is extracted from seeds, dye is extracted from above ground parts etc. Since, the accessions of safflower differed from each other in their genotypes; these findings indicated that not only the accumulation of mercury and selenium but also its translocation from root to shoot was genotype dependent. Since, wild accumulators of metal often accumulate certain specific element, grow slowly and finally develop small biomass. Many crops and relevant wild species have been screened for metal uptake, translocation and tolerance. Much attention has centered on Brassicaceae, having many metal hyper accumulators [29-37]. Taken together these results with the previous studies [31-35], there is a clear cut indication that many toxic metals can easily be taken up followed by their well defined sequestration in roots and shoots. Moreover, translocation of these metals to shoots as well as tolerance for these was limited [38].

Metal accumulation has been recognized as a specific but extreme physiological response in heavy metal tolerance [39]. Various degrees of metal accumulation was recognizable, ranging from a micro level elevation above 'background' to an extreme response where a metal might constitute in excess of $1 \%$ of plant dry matter. Metal accumulation by plants also depends upon chemical form of the element in solution. Accumulators were capable of concentrating metals in aboveground parts, in vascular plants, to an extraordinary degree, from a low or high substrate concentration. An accumulator is a species whose metal concentration exceeds the normal values for metal concentrations in plants for a particular substrate. Analysis of plant parts suggests a general tendency for accumulators to translocate most metal taken up from root to shoot. Because of it, concentrations recorded in the aerial plant parts are generally substantially higher than in roots. Accumulation of heavy metals in different biological systems has been presented by several workers [40-47].

\section{CONCLUSIONS}

Data obtained from this study entail that the amount of mercury and selenium accumulated in shoots was much less 
in comparison to those in roots. Safflower has recognition as an economically important plant for providing dye 'Carthamin' from its floral parts and oil from its seeds, while grains are used to feed poultry and livestock etc. Conclusively, the present study provides new insights into conjugates can be extracted with negligible concentration of $\mathrm{Hg}$ and Se occurring in aerial parts of this economically and nutraceutically significant plant.

\section{ACKNOWLEDGEMENTS}

The present paper is a section of Ph.D. studies carried out by author, NM who was registered at Department of Botany, CCS University, Meerut, UP, India, and currently being associated with the research group of Prof. Sanjay Mishra.

\section{REFERENCES}

[1] Mudgal V, Madaan N, Mudgal A, Singh RB, Mishra S. Effect of toxic metals on human health. Open Nutra J 2010; 3: 94-9.

[2] Nriagu JO. Global inventory of natural and anthropogenic emissions of trace metals to the atmosphere. Nature 1979; 279: 409-11.

[3] Kabata-Pendias A, Pendias H. Trace Elements in the Soil and Plants, $3^{\text {rd }}$ Edition; Florida: CRC Press 2000.

[4] Schauss AG. Selenium 2003; <http://www.traceminerals.com/ products/selenium.html>

[5] Taylor EW. Selenium and cellular immunity. Evidence that selenoproteins may be encoded in the +1 reading frame overlapping the human CD4, CD8, and HLA-DR genes. Biol Trace Elem Res 1995; 49: 85-95.

[6] Kiremidjian-Schumacher L, Roy M, Wishe HI, Cohen MW, Strotzky G. Supplementation with selenium and human immune cell functions. 2. Effect on cytotoxic lymphocytes and natural killer cells. Biol Trace Elem Res 1994; 41: 115-27.

[7] Roy M, Kiremidjian-Schumacher L, Wishe H, Cohen MW, Stotzy G. Supplementation with selenium and human immune cell functions 1. Effect on lymphocyte proliferation and interleukin 2 receptor expression. Biol Trace Elem Res 1994; 41: 103-14.

[8] Srivastava R, Sharma R, Mishra S, Singh RB. Biochemical and molecular biological studies in oral cancer: An overview. Open Nutra J 2011; 4: In Press.

[9] Clark LC, Combs GF, Turnbull BW, et al. Effects of selenium supplementation for cancer prevention in patients with carcinoma of the skin: A randomized controlled trial. J Am Med Assoc 1996; 276: 1957-63.

[10] Turesson G. The genotypical response of the plant species to the habitat. Hereditas 1992; 3: 211-350.

[11] Molles, Manuel CJ. Ecology: Concepts and Applications. 2005; edition 3rd, pp.201, ISDN 0-07-243969-6. The McGraw Hill Companies Inc., New York.

[12] Brimblecombe B, Cunningham MA, Cunningham WP, Freedman. Environmental Encyclopedia. Edition 3rd, pp. 435.

[13] Aggarwal R, Srivastava AK. Quantification of the Differential Effects of Hg++ on Barley. J Ind Bot Soc 2000; 79: 55-9.

[14] Srivastava AK, Purnima. Some facets of Heavy Metal Tolerance in Higher Plants. J. Ind Bot Soc 1999; 78: 271-85.

[15] Tong YP, Kneer R, Zhu YG. Vacuolar compartmentalization: a second-generation approach to engineering plants for phytoremediation. Trends Plant Sci 2004; 9: 7-9.

[16] Verret F, Gravot A, Auroy P, et al. Overexpression of AtHMA4 enhances root-to-shoot translocation of zinc and cadmium and plant metal tolerance. FEBS Lett 2004; 576: 306-12

[17] Song WY, Sohn EJ, Martinoia E, et al. Engineering tolerance and accumulation of lead and cadmium in transgenic plants. Nature Biotech 2003; 21: 914-9.

[18] Hirschi ED, Korenkey VD, Wilganewski NI and Wagner GI. Expression of Arabidopsis CAX2 in tobacco. Altered metal accumulation and increased manganese tolerance. Plant Physiol 2000; 124: 128-33.
[19] Antosiewicz DM, Hennig J. Overexpression of LCT1 in tobacco enhances the protective action of calcium against cadmium toxicity. Environ Pollut 2004; 129: 237-45.

[20] Papoyan A, Kochian LV. Identification of Thlaspi caerulescens genes that may be involved in heavy metal hyperaccumulation and tolerance. Characterization of a novel heavy metal transporting ATPase. Plant Physiol 2004; 136: 3814-23.

[21] Bovet L, Feller U, Martinoia E. Possible involvement of plant ABC transporters in cadmium detoxification: a cDNA sub-microarray approach. Environ Intl 2005; 31: 263-7.

[22] Baker AJM, Walker PL. Ecophysiology of metal uptake by tolerant plants, heavy metal tolerance in Plants. In: Shaw AJ. Evolutionary Aspects: CRC Press, Boca Raton, 1990; pp. 155-77.

[23] Tian JL, Zhu HT, Yang YA, He YK. Organic mercury tolerance, absorption and transformation in Spartina plants. Zhi Wu Sheng Li Yu Fen Zi Sheng Wu Xue Xue Bao 2004; 30: 577-82.

[24] Bennicelli R, Stepniewska Z, Banach A, et al. The ability of Azolla caroliniana to remove heavy metals $(\mathrm{Hg}(\mathrm{II}), \mathrm{Cr}(\mathrm{III}), \mathrm{Cr}(\mathrm{VI}))$ from municipal waste water. Chemosphere 2004; 55: 141-6.

[25] Pilon-Smits EAH, Hwang S, Lytle C, et al. Overexpression of ATP sulfurylase in Indian mustard leads to increased selenate uptake, reduction and tolerance. Plant Physiol 1999; 119: 123-32.

[26] Wangeline AL, Burkhead JL, Hale K, et al. Overexpression of ATP sulfurylase in Indian mustard: Effects on tolerance and accumulation of twelve metals. J Env Qual 2004; 33: 54-60.

[27] Madaan N. Ph.D. Thesis, Analysis of genetic variability and inheritance for some heavy metal tolerance in oil crop Carthamus tinctorius L. 2008; CCS University, India.

[28] LeDuc DL, Tarun AS, Montes-Bayon M, et al. Overexpression of selenocysteine methyltransferase in Arabidopsis and Indian mustard increases selenium tolerance and accumulation. Plant Physiol 2004; 135: 377-83.

[29] Kumar PBAN, Dushenkov S, Salt DE, Raskin I. Crucifereae Newsletter 1994; 16: 18-9.

[30] Kumar PBAN, Dushenkov V, Motto H, Raskin I. Phytoextraction: The Use of plants to remove heavy metals from soils. Environ Sci Technol 1995: 29: 1232-8.

[31] Raskin I, Kumar PBAN, Dushenkov V, Salt DE. Bioconcentration of heavy metals by plants. Curr Opin Biotechnol 1994; 5(3): 285-90.

[32] Salt, DE, Prince RC, Pickering IJ, Raskin I. Mechanisms of cadmium mobility and accumulation in Indian mustard. Plant Physiol 1995; 109: 1427-30.

[33] Adler T. Botanical cleanup crews. Sci News 1996; 150: 42-3.

[34] De Souza MP, Pilon-Smits EAH, Lytle CM, et al. Rate- limiting steps in selenium assimilation and volatilization by Indian mustard. Plt Physiol 1998; 117: 1487-94.

[35] De Souza MP, Chu D, Zhao M, et al. Rhizosphere bacteria enhance selenium assimilation and volatilization by Indian mustard. Plt Physiol 1999; 119: 565-74.

[36] De Souza MP, Lytle CM, Mulholand MM, et al. Selenium assimilation and volatilization from dimethylselenonioproponate by Indian mustard. Plant Physiol 2000; 122: 1281-8.

[37] Pickering IJ, Prince RC, George MJ. Reduction and coordination of arsenic in Indian mustard. Plant Physiol 2001; 122: 1171-8.

[38] Cunningham SD, Bert WR, Huang JW. Phytoremediation of contaminated soils. Trends Biotechnol 1995; 13: 393-7.

[39] Peterson PJ. Tolerance, a plant's response to metal stress. In: Mineral Exploration, Biological Systems and Organic Matters, 1986; Vol. 5, pp. 60. Prentice-Hall, Englewood Cliffs, New Jersey.

[40] Garcia WJ, Blessin CW, Stanford HW, Inglett GE. Translocation andaccumulation of seven heavy metals in tissues of corn plants on sludge-treated strip-mined soil. J Agric Food Chem 1979; 27: 1088-94.

[41] Ferrara R, Maserti BE, Bargali R. Mercury in the atmosphere and in lichens in a region affected by a geochemical anomaly. Enviro Technolo Letter 1988; 9: 689-92.

[42] Jensen PK, Baatrup E. Histochemical demonstration of mercury in the intestine, nephridia and epidermis of the marine polychaete $\mathrm{Ne}$ reis virens exposed to inorganic mercury. Marine Biol 1988; 97: 533-40.

[43] Mosbaek H, Tjell JC, Sevel T. Plant uptake of airborne mercury in background areas Chemosphere 1988; 17: 1227-36. 
[44] Gopal V, Devi KM. Proceedings of the Fifty-Ninth Annual Session of National Academy of Sciences, Allahabad, India 1989; pp 139.

[45] Rao PV, Jordan SA, Bhatnagar NK. Ultrastructure of kidney of ducks exposed to methylmercury, lead and cadmium in combination. J Environ Pathol Toxicol Oncol 1989; 9: 19-44.
[46] Grant CA, Bruckey WT, Bailey LD, Selles F. Cadmium accumulation in crops. Can J of Plant Sci 1998; 7: 1-17.

[47] Madaan N, Mudgal V. Differential Tolerance Behaviour of Safflower Accessions to Some Heavy Metals. Int J Applied Environmental Sci 2009; 4: 413-20.

Received: September 20, 2011

Revised: September 30, 2011

Accepted: September 30, 2011

(C) Madaan et al.; Licensee Bentham Open.

This is an open access article licensed under the terms of the Creative Commons Attribution Non-Commercial License (http://creativecommons. org/licenses/ by-nc/3. 0/) which permits unrestricted, non-commercial use, distribution and reproduction in any medium, provided the work is properly cited. 